Michał Kopczyk (iD) https://orcid.org/0000-0001-5885-8702 Akademia Techniczno-Humanistyczna w Bielsku-Białej mkopczyk@ath.bielsko.pl

\title{
Mądry błazen, szpital wariatów i geopolityka. Dzienniki Stefana Kisielewskiego jako narracja kontrhegemoniczna
}

\author{
The Wise Jester, the Madhouse, and Geopolitics. Dzienniki by Stefan Kisielewski \\ as a Counter-Hegemonic Narrative
}

\begin{abstract}
This article proposes a reading of Dzienniki [Diaries] by Stefan Kisielewski (19111991) as a counter-hegemonic narrative. The author of this article explores the question of the strategy that Kisielewski adopts (consciously or not) in response to the conditions in which he finds himself as a writer and publicist - that is, the textual strategy (devised for the purposes of a specific work, his diary) and the life strategy. The principal element in the strategy employed by the writer is his embrace of the role of a jester - a commentator of reality, who finds pleasure in the rhetorical advantage granted by categories such as: joke, ridicule, irony, and self-mockery. This attitude allows one to attain a distance to both the world and other people, which guarantees safety and also helps sidestep most of the dangers associated with placing too much confidence in reason. The jester mask precludes dogmatism, prevents devoting oneself completely to the pragmatism of fighting an enemy, and allows maintaining individual autonomy in an oppressive world.
\end{abstract}

Keywords: Stefan Kisielewski, counter-hegemonic narrative, diary, jester

Streszczenie: Artykuł jest propozycją lektury Dzienników Stefana Kisielewskiego (19111991) jako narracji kontrhegemonicznej. Autora artykułu interesuje pytanie o (świadomą lub nie) strategię Kisielewskiego, będącą odpowiedzią na warunki, w jakich przyszło mu być pisarzem i publicystą - strategię tekstową (stworzoną na użytek konkretnego dzieła, jakim jest dziennik) oraz życiową. W ocenie autora artykułu najważniejszym elementem stosowanej przez pisarza strategii jest wcielanie się w rolę błazna - komentatora rzeczywistości, z upodobaniem wykorzystującego retoryczne zalety takich kategorii, jak żart, kpina, ironia, autoironia. Postawa taka pozwala osiągnąć dystans do świata i ludzi, zapewnia bezpieczeństwo, a także pozwala uniknąć większości zagrożeń, jakie niesie z sobą zbytnie zaufanie do rozumu. Maska błazna wyklucza dogmatyzm, nie pozwala na podporządkowanie się bez 
reszty pragmatyce walki z wrogiem, umożliwia zachowanie jednostkowej autonomii w opresyjnym świecie.

Słowa kluczowe: Stefan Kisielewski, narracja kontrhegemoniczna, dziennik, błazen

Stefan Kisielewski należał do tych przedstawicieli elity intelektualnej czasu PRL-u, którzy ustrzegli się nie tylko „romansu z systemem”, ale i jakichkolwiek złudzeń co do jego prawdziwej natury. Swój dziennik zaczął prowadzić w wieku 57 lat jako pisarz i publicysta o wielkim dorobku i sprecyzowanych poglądach, niewierzący już w skuteczność legalistycznych metod oddziaływania na władzę. Po antysemickiej nagonce i wydarzeniach marcowych nie miał wątpliwości, że przedsięwzięcie znane jako Koło Poselskie „Znak” nie spełniło pokładanych w nim nadziei, że poległo w starciu z przeciwnikiem o wiele silniejszym i zręczniejszym w politycznych rozgrywkach ${ }^{1}$.

W artykule tym spojrzę na dziennik autora Sprzysiężenia jako na narrację kontrhegemoniczną, zakładając, że u jego podstaw leży przekonanie diarysty o zasadniczo opresyjnym charakterze opisywanej rzeczywistości oraz dążenie do zrozumienia i wskazania skutków, jakie na szeroko rozumiane życie społeczne i świadomość zbiorową w Polsce i innych krajach komunistycznych regionu wywierają reguły realnego socjalizmu oraz uzależnienie od Związku Radzieckiego. Interesuje mnie również pytanie o (świadomą lub nie) strategię Kisielewskiego, będącą odpowiedzią na warunki, w jakich przyszło mu być pisarzem, komentatorem rzeczywistości, przedstawicielem umysłowej elity - strategię tekstową (stworzoną na użytek konkretnego dzieła, jakim jest dziennik) oraz życiową.

Pytaniom, które stawiam, towarzyszy przekonanie, że każdy tekst autobiograficzny nie tylko reprezentuje rzeczywistość, ale także ją konstruuje. Reprezentacji oraz konstrukcji podlegają przede wszystkim autor i jego tekstowy odpowiednik - bohater dziennika - i to niezależnie od tego, czy badany tekst podporządkowany jest strategii autokreacyjnej, czy nie. Działania autora nie stanowią w zasadzie przedmiotu oceny z perspektywy moralnej (kwestia kłamstwa), w przypadku dziennika zaś z pewnością należy z ostrożnością posługiwać się kategoriami prawda-fałsz i założyć, że nawet świadoma mistyfikacja

1 Temat ten często gości na kartach dziennika. Choć oceny Kisielewskiego odnoszące się do konkretnych działań Koła bywały różne, ogólny ton jego komentarzy jest pesymistyczny, co wynikało - jak można sądzić - z generalnego zwątpienia w korzyści, jakie przyniosła jego działalność. Por. s. 111-112, 129, 224, 557, 566. Odwołania do Dzienników Kisielewskiego lokalizuję według wydania z 1996 roku (Warszawa, wprowadzenie L.B. Grzeniewski). 
ujawnia jakąś prawdę o osobie, która ją stosuję $e^{2}$ Nie zmienia to oczywiście faktu, że jednym z głównych powodów skłaniających czytelników do zagłębiania się w cudze zapiski jest pragnienie zbliżenia się do prawdy - o głównym bohaterze i świecie, w którym żył.

\section{II}

Można powiedzieć, że w dziennik Stefana Kisielewskiego wpisane są dwa fundamentalne paradoksy. Pierwszy jest skutkiem sprzeczności między przyjętą przez autora rolą stratega, równoznaczną z formułowaniem zaleceń naprawczych odnoszących się do rzeczywistości, a niezachwianym przekonaniem, że rzeczywistość ta jest niepodatna na wszelkie próby poprawy oraz że warunkiem wstępnym jakichkolwiek pozytywnych przeobrażeń jest zmiana ustroju. Twardy, broniony dogmatycznie światopogląd, sprzeczny z zasadami ekonomii czy po prostu zdrowym rozsądkiem, stanowi skuteczną barierę dla ewentualnych prób ewolucyjnego racjonalizowania sposobu sprawowania władzy. Właśnie owa nieracjonalność stanie się w ustach diarysty zarzutem najcięższym, najczęściej ponawianym i nadającym ulubionej przez niego formule „dom wariatów” (s. 54, 57, 114, $249 \mathrm{i}$ in.) status czegoś więcej niż wyłącznie dosadnego epitetu.

Drugi paradoks wiąże się pragmatyką dziennika. Bezpośrednim impulsem do decyzji o rozpoczęciu jego pisania był oficjalny zakaz druku, jakim objęto nazwisko pisarza w reakcji na wystąpienie na nadzwyczajnym Zjeździe Związku Literatów Polskich w lutym 1968 roku (to wtedy padły słowa o „dyktaturze ciemniaków"). Pozbawiony możliwości dotarcia do czytelnika Kisielewski postanowił pisać „do szuflady”, świadom, że szanse na publikację zapisków w dającej się przewidzieć przyszłości są bliskie zera, a tym samym, że jego diagnozy czy komentarze (a większość z nich dotyczyła spraw szybko tracących aktualność) trafiają w pustkę.

Pisany bez myśli o druku dziennik stanowi zapis sekretny w dosłownym znaczeniu tego słowa, a więc dzieło, którego twórca jest zarazem jego jedynym założonym odbiorcą. Można powiedzieć, że funkcja notatek sprowadza się w takiej sytuacji do działania autoterapeutycznego: zapisuję, zdaje się mówić autor,

2 W tej kwestii zgadzam się z Pawłem Rodakiem: „Można powiedzieć, że w dzienniku historia i osoba spotykają się ze sobą w materialności zapisu. To właśnie materialny zapis, noszący na sobie ślad ludzkiej ręki, a zarazem poddany czasowemu procesowi starzenia jest gwarantem prawdy. Prawda, o której tu mowa, nie jest przy tym kategorią opozycyjną ani w stosunku do kłamstwa czy fałszu (te mogą się w dzienniku pojawiać), ani w stosunku do kreacji (która w dzienniku pojawić się musi). Nawet gdyby autor dziennika notorycznie w nim kłamał czy fantazjował, to i tak jego dziennik, z przyjętego tu punktu widzenia, będzie prawdziwy. Będzie bowiem ujawniał prawdę o kłamiącej osobie i skłamanej przez nią rzeczywistości” (P. Rodak, Prawda w dzienniku osobistym, „Teksty Drugie” 2009, nr 4, s. 27). 
by lepiej rozumieć, by przeżyć raz jeszcze, bardziej świadomie, co najwyżej zapisuję dla potomnych. Dziennik jest przede wszystkim medium namysłu nad rzeczywistością oraz umieszczonym w niej autorem, a jednocześnie sposobem na wzmocnienie istnienia autora w rzeczywistości („wytrzymywać”). Pierwsza funkcja - jak podpowiada Philippe Lejeune - otwiera dziennik na czas przyszły ${ }^{3}$, druga - czyni z niego miejsce poszukiwania odpowiedzi na pytanie: „Jak dać sobie radę, kiedy życie poddaje nas jakiejś strasznej próbie? Jak zmienić swoje wnętrze w warowny obóz, gdzie przygotowuje się do walki i nabiera sił?”4. W tym sensie moment rozpoczęcia przez Kisielewskiego pisania dziennika okazuje się wymowny - każe odczytać dziennik jako obronę przed zniknięciem, osunięciem się w niebyt w sytuacji, gdy ów byt został znacząco ograniczony w wymiarze publicznym ${ }^{5}$.

Wybór dziennika nie oznacza jednak w tym wypadku poddania się konwencji - a ta wyraźnie skłania do koncentrowania się na sobie. Pisarz oczywiście jest najważniejszym bohaterem swego dziennika i nawet komentowana z pasją dookolna rzeczywistość nie może zepchnąć go na dalszy plan; mimo to trudno znaleźć tu tak charakterystyczne dla dziennika intymnego skupienie na sobie, egotyzm, każący zaczerniać kartki analizą własnych przeżyć wewnętrznych. Bohater przeważnie widziany jest z dystansu, jaki stwarzają autoironia i autorefleksja ${ }^{6}$, co nasuwa wniosek, że gatunkowym wzorcem dla dziennika Kisielewskiego jest felieton $-\mathrm{z}$ charakterystyczną dla niego perspektywą subiektywną, ale i zainteresowaniem światem zewnętrznym w jego aktualnych przejawach ${ }^{7}$. To więc nie diarysta poddaje się ciążeniu gatunku, lecz sam w ów gatunek wprowadza własną osobowość i nawyki pisarskie. Dziennik ma przy tym zaletę, której nie posiada felieton - uwalnia od konieczności stałej gry,

3 Mówiący dokonuje „bilansu dnia dzisiejszego, by przygotować się do działania, które rozpocznie jutro. (...) pisanie zmusza do określenia wyzwań i sformułowania argumentów, pozostawiając ślady, do których można będzie wrócić we własnych refleksjach. Diariusz pozwala także czuwać nad "ciągiem dalszym « dokonanego wyboru”. Ph. Lejeune, „Drogi zeszycie...”, „drogi ekranie...”. O dziennikach osobistych, tłum. A. Karpowicz, M., P. Rodakowie, wybór, wstęp P. Rodak, Warszawa 2010, s. 41.

4 Tamże.

5 Zakaz druku nie przerwał całkowicie działalności publicystycznej Kisielewskiego, nie trwał także szczególnie długo (do 1970 roku). Pomoc redaktorów z kręgu „Tygodnika Powszechnego" umożliwiała mu publikowanie artykułów i recenzji pod pseudonimami, teksty te dotyczyły jednak głównie tematyki literackiej lub muzycznej, nie mogły więc zaspokoić pasji polemicznej ich autora. Nie miały tej siły także powieści ogłaszane (pod pseudonimem) w oficynie Instytutu Literackiego w Paryżu, w niewielkim stopniu tylko przenikające do kraju.

6 Skłonność diarysty do autoironii Andrzej Nowak zdaje się traktować wręcz jako dominantę całego dziennika. Tenże, Powrót do Polski. Szkice o patriotyzmie po „końcu historii”, Kraków 2005, s. 179.

P. Stasiński, Poetyka i pragmatyka felietonu, Wrocław 1982, s. 8. Genetyczne pokrewieństwo zapisów dziennika Kisielewskiego z felietonem dostrzegła już Monika Wiszniowska. Por. taż, Sztuka felietonu Stefana Kisielewskiego, Katowice 2013. 
nie tylko z cenzorami i redaktorami czasopism, lecz i z samym sobą, czy raczej z własną cenzurą wewnętrzną.

Niezależnie od „profitów”, jakie dostarczała forma dziennikowa, niemożność dotarcia ze swym przekazem do czytelnika była dla pisarza brzemieniem. Położenie, w jakim się znalazł w 1968 roku, można by opisać za pomocą znanej opinii Czesława Miłosza, porównującej sytuację emigranta tworzącego w języku polskim do kogoś, kto chowa swe manuskrypty w dziuplach drzew. Trudno się więc dziwić, że notatki z tego okresu nie emanują optymizmem:

I co ja tu mam właściwie do roboty? Pisać powieści do szuflady - zgoda, ale jak długo wytrzymam w tej izolacji, czy nie zdziwaczeję lub nie załamię się, jak to przepowiadał Paweł [Hertz - dop. M.K.]? Poczułem nagłą rozpacz, ale przecież wywiać jak Tyrmand to oznacza albo karmić się emigranckimi mitami, albo też porzucić polską problematykę, co z kolei oznacza przyznanie się do przerwanego i zmarnowanego życia! A więc - trzeba pisać, oszołamiać się tym, może także muzykę? Może pozwolą powrócić do życia, ale już oczywiście nie w charakterze tolerowanego quasi-opozycjonisty, lecz musiałbym złożyć jakiś akt afirmacji, włączyć się w życie takie, jakim ono jest. Nie mam na to już sił (nie wspominając o przekonaniu), a w przełom w rodzaju czeskiego w tym kraju nie wierzę - Moskale nie pozwolą. Mam więc żyć nieużyteczny albo też uciec niesławnie i skończyć bez środowiska, otoczenia, bez własnej publiczności, bez ojczyzny, patetycznie mówiąc? (s. 74)

Po pobiciu przez „nieznanych sprawców” i objęciu go zapisem Kisielewski wiedział już, że dramaturgia jego rozmów z czytelnikami i władzą toczy się według reguł, które ustala wyłącznie ta ostatnia. W pierwszym roku pisania dziennika często dochodzi do głosu zwątpienie w sens działalności publicystycznej, rozczarowanie osiągniętymi efektami, poczucie niemożności i pesymizm w kwestii możliwości dotarcia do odbiorcy. Te chwile słabości nie są na szczęście na tyle częste, by zniechęcić diarystę do prowadzenia zapisków. Nad argumentami rozumowymi i potrzebą reakcji ze strony świata górę bierze zawsze pasja - pasja komentowania, replikowania, oceniania i snucia prognoz.

\section{III}

Sformułowane w dzienniku charakterystyki sytuacji, w jakiej znalazła się po wojnie Polska i inne kraje radzieckiej strefy wpływów, tworzą w sumie spójny obraz obszaru niesamodzielnego, podporządkowanego wschodniemu imperium, z narzuconym mu nieracjonalnym ustrojem polityczno-ekonomicznym oraz miejscowymi elitami pozbawionymi decydującego wpływu na rzeczywistość. Kisielewski nie wierzył w możliwość zmiany tej sytuacji, w czym utwierdzała go analiza położenia geopolitycznego Polski, w tym zwłaszcza działania 
Związku Radzieckiego, zdecydowanego za wszelką cenę nie dopuścić do zmiany status quo (vide inwazja na Czechosłowację) czy choćby znaczącej liberalizacji w jakimkolwiek państwie bloku.

Także Zachód nie był zainteresowany doprowadzeniem do zmian w aktualnym układzie sił. Diarysta nie ma wątpliwości, że ten nie zaryzykuje narażenia swego spokoju w imię upominania się o demokrację w krajach Europy Środkowej i Wschodniej i postawi raczej na politykę łagodzenia napięć, kosztem ustępstw wobec wschodniego imperium. Co charakterystyczne, Kisielewski nie tylko rozumie, ale i usprawiedliwia taką strategię, a jego krytyka skupia się głównie na wskazywaniu niekonsekwencji w niej, które umiejętnie wykorzystuje Związek Radziecki, będący graczem na ogół skuteczniejszym i bardziej bezwzględnym. Zachód bywa „egoistyczny i głupi” (s. 376), a gra, którą prowadzi, podporządkowana jest jego własnym interesom, a jednak jego istnienie jako obiektu aspiracji i wiary w realność wartości demokratycznych wspiera aspiracje wolnościowe w „gorszej” części kontynentu i pomaga uniknąć zupełnej sowietyzacji.

Polska „nierzeczywistość”, jaka wyłania się z notatek dziennika, to świat pozbawiony patosu i nie demoniczny bynajmniej, raczej gospodarstwo rządzone twardą ręką „,iemniaków” i dyletantów czujących nad sobą jeszcze silniejszego pana, a także oddech społeczeństwa, które w każdej chwili może wypowiedzieć im wojnę. Binarny podział na „swoich” i „obcych” - winnych, oprawców (i ich popleczników) oraz niewinne ofiary - nie ma tu decydującego znaczenia w ocenie ludzi czy zjawisk. Ważniejsze dla diarysty są niuanse, wydobywanie tego, co dzieje się na marginesie zjawisk o generalnym znaczeniu. Wolność od małostkowości i zacietrzewienia pozwala mu na przykład zauważyć, że również „sługi systemu” bywają też jego ofiarami, lub opisać rozpowszechnioną wśród elit partyjnych skłonność do demonstrowania dystansu do odgrywanej roli. Porozumiewawcze „puszczanie oka” do społeczeństwa odczyta jako element strategii przystosowawczej, polegającej na budowaniu szczególnej wspólnoty ofiar, ludzi złączonych przymusem życia w świecie, którego charakter określają siły najzupełniej obojętne wobec ich pragnień i ambicji. W tym sensie wschodni hegemon pełnił przez kilka dekad funkcję usprawiedliwienia dla działań kolejnych ekip rządzących. W oczach Kisielewskiego to więc nie tyle społeczeństwo ucieka się do mimikry - naśladowania swych ciemiężycieli, by podwyższyć swój status $^{8}$ - ile raczej elity polityczne szukają sposobów, by zatrzeć w oczach społeczeństwa stygmat innych, obcych, znienawidzonych „onych”.

8 Teoretyk postkolonializmu Homi Bhabha rozumie mimikrę jako postawę naznaczoną dwoistością, wynikającą z dążenia podmiotu podporządkowanego (skolonizowanego) do tego, by upodobnić się do ciemiężcy (kolonizatora), „ale nie całkiem”, a które, „aby było skuteczne, musi bezustannie demonstrować swoje ześlizgiwanie się znaczenia, swój nadmiar, swoją różnicę" (H. Bhabha, Miejsca kultury, tłum. T. Dobrogoszcz, Kraków 2010, s. 80). Ostatecznie ów podmiot istnieje w sposób nieokreślony do końca, zmienny, polaryzujący, „częściowy”, 
W latach siedemdziesiątych opisze Kisielewski zjawisko, które wiele dekad później Andrzej Leder określi jako „prześnioną rewolucję”. W owej - jak to nazwie - „chłopskiej rewolucji pragmatycznej” zobaczy jeszcze jeden powód do pesymistycznych (i na szczęście niesłusznych) przewidywań:

W tej sytuacji masa nie poprze żadnych inteligenckich postulatów wolnościowych, dla niedawnych analfabetów wolność słowa jest pustym dźwiękiem, czują się awansowani, nie chcą awansu utracić - stąd też nie ma odwrotu od ustroju nawet w krajach, które wyswobodziły się od „opieki” Rosji, jak Albania, Jugosławia, Kuba (s. 642).

Rozpoznania Kisielewskiego przeczą pielęgnowanej przez większość jego współczesnych wizji wspólnoty ofiar, która pod plugawą powierzchnią podtrzymuje żar gorącej lawy. Obojętność milczącej większości na „wielkie słowa" przypominane przez opozycję uważał, oprócz układu geopolitycznego, za główny powód swego sceptycyzmu co do realności przyszłych zmian w całej Europie Wschodniej. O charakterze umysłowości autora Sprzysiężenia wiele mówi przy tym fakt, że swego stanowiska w tej kwestii nie zmienił nawet po powstaniu KOR-u. Nie dostrzegł w nim potencjału zdolnego przekształcić się w znaczącą platformę działań politycznych, jaką cztery lata później okaże się Solidarność. Nie wierzył w skuteczność strategii obranej przez opozycyjnych „radykałów” (a za takich uważał między innymi Jacka Kuronia i Karola Modzelewskiego), przekonany, że nie liczy się ona z realiami chwili. Krytycyzm, a nawet niechęć do liderów opozycji miała, jak się zdaje, i głębsze powody. Wynikała z niewiary nie tylko w możliwość naprawy systemu postulowanej przez „rewizjonistów” (a do nich zaliczał pisarz również Kuronia i Modzelewskiego), ale i w lewicowość jako taką. Przywiązany do ideałów liberalnych, do zasady wolnej konkurencji i wolności indywidualnej Kisielewski nie akceptował niczego, co mogło te wartości ograniczyć, bez względu na racje, jakie takie ograniczenia uzasadniały. Obiektem swej krytyki uczynił nie tylko wcielony w życie komunizm, ale także Europę Zachodnią, uwiedzioną fałszywą i szkodliwą jego zdaniem wizją państwa troszczącego się o swych obywateli, w istocie jednak pozbawiającego ich autonomii. Te przekonania były punktem wyjścia do prób rozumienia świata podejmowanych przez pisarza, stały one również za jego „przepowiedniami” odnoszącymi się do bliższej i dalszej przyszłości. Te z nich, które dotyczyły zjawisk ściśle politycznych, oparte były przy tym na niezachwianej wierze w decydujące znaczenie geopolityki jako czynnika kształtującego rzeczywistość w kraju. Z takiej perspektywy ruch dysydencki wydawał się marnowaniem społecznej energii, z góry skazanym na klęskę, niemającym bowiem

„niepełny” i „wirtualny” (tamże, s. 81). W perspektywie, jaką proponuje Kisielewski, mamy do czynienia z odwróceniem ról. 
żadnego wpływu na równowagę sił na świecie? . Należało odrzucić romantyczny sztafaż, unikać narodowowyzwoleńczych uniesień i przyjąć raczej postawę ,patriotyzmu rozumnego" ${ }^{10}$. Tak pojmowany patriotyzm oznaczał wybór drogi środkarezygnację z wygórowanych oczekiwań, ale i niepopadanie w - jak to określał - „realistyczny oportunizm”, będący w istocie kapitulacją (ten zarzut padnie w dzienniku między innymi pod adresem Ludwika Stommy). W listopadzie 1976 roku pisarz zanotował $\mathrm{w}$ dzienniku rodzaj osobistego credo:

Osobiście zakreśliłem sobie „plan minimum”. Ustroju się nie zmieni, trzeba jednak działać, aby wychowywać zarazem rządzących i rządzonych. Rządzący zagrożeni są sklerozą, nieustanne powtarzanie sowieckich bzdur musi ich zdegenerować. A znów rządzeni przestają rozumieć, gdzie żyją, zapominają w ogóle, że mogłoby być inaczej, biorą nieustający bełkot propagandy za język normalny. Trzeba wychowywać jednych i drugich, pierwszym przypominając, że są tu tylko z łaski Rosji, że nie są właścicielami tylko dzierżawcami, drugim, że nadmierny strach i potulność nic im nie dadzą. A więc działalność pedagogiczno-propagandowa oczywiście tylko do pewnych granic, aby nie doszło do sowieckich czołgów i drugiej Czechosłowacji. Aby ta działalność pedagogiczna była skuteczna, musi mieć swój instrument. Informacji - dotąd była nim „Wolna Europa”, teraz zaczynają się tajne biuletyny, czyli „samizdat” (...). (...) ja się trzymam trochę na boku, chcę przecież pisać, no

9 Być może na oceny pisarza miały wpływ osobiste idiosynkrazje, a także różnica pokoleniowa utrudniająca rozumienie postaw tych, których umysły ukształtowało już życie w realnym socjalizmie. Z czasem (zwłaszcza po powstaniu drugiego obiegu) ostrość ocen zmniejszyła się, a obok krytycznych uwag pojawiły się wyrazy solidarności i podziwu dla zaangażowania działaczy. Zapis z 30 grudnia 1976 roku wydaje się charakterystyczny dla tonu wypowiedzi pisarza z tego czasu: „Czyż skuteczną przeciwwagę dla mafii mogą stworzyć Kuroń, Lipski lub Ziębiński, bezbronni w gruncie rzeczy i pozbawieni oparcia, choć czepiają się rozpaczliwie to robotników, to prasy zagranicznej, obojętnej w gruncie rzeczy i tylko żądnej sensacji? Owszem, Piłsudskiemu za caratu się to udało, ale jemu pomogły wojny $(1905,1914)$, napięcia i wstrząsy w samej Rosji, wreszcie polityka mocarstw inna w każdym zaborze. Teraz niczego takiego nie ma, stąd i donkichotyczność naszych kontestatorów. Chociaż - nigdy nie trzeba się całkiem zarzekać... Działają przecież pobudzająco, uświadamiająco, wychowawczo. Bóg z nimi!” (s. 891).

10 Tomasz Sikorski słusznie zauważył: „Posiłkując się lekturą swoich mistrzów, Michała Bobrzyńskiego, Aleksandra Świętochowskiego i Romana Dmowskiego starał się przekonywać czytelnika, że należy wypracować podstawy pod "patriotyzm rozumny", roztropny, mądry i przenikliwy, pozwalający mierzyć siły na zamiary. W dążeniu do celów zasadniczych należało wykazać się czujnością, ostrożnością, nie można było osiągnąć niepodległości bez kolejnych etapów do niej prowadzących, na skróty. Krytykował więc uporczywie zwolenników narodowych zrywów, cierpiętników i martyrologów, przypominając, że niemal wszystkie powstania kończyły się klęskami i fatalnymi skutkami. Jednostkowy honorowy patriotyzm zaprzeczał myśleniu wspólnotowemu. W kontekście powstania warszawskiego pisał, że instynkt racji stanu nie pozwala na walkę o jednostkowy honor, kosztem potencjału cywilizacyjnego, kulturowego i materialnego. T. Sikorski, „Ale cóż robić, kiedy Rosję tak trudno kochać...” Refleksje nad realizmem politycznym Stefana Kisielewskiego [w:] Rosja w polskiej myśli politycznej XX-XXI wieku, red. A. Lewandowski, W. Wojdyło, G. Radomski, Toruń 2013, s. 122. 
i mam „Tygodnik”, który swą pępowiną łączy mnie z życiem „normalnym”. Ale i to się skończy - nie wątpię. W końcu wszyscy oberwiemy (s. 885).

Realizm nie pozwalał Kisielewskiemu wyobrazić sobie zmian, które następują nieoczekiwanie, skokowo, pozornie bez powodu, nagłych i radykalnych; przyjąć, że politologia nie jest dziedziną ścisłą, a dzieje nie zawsze realizują plany strategów. To być może sprawiło, że tak wiele jego prognoz się nie sprawdziło. $\mathrm{Z}$ kolei niechęć do romantycznych zrywów rodziła konflikty (także ze środowiskami czy osobami bliskimi mu światopoglądowo) i poczucie osamotnienia. Nie ma jednak w dzienniku tonu cierpiętniczego, goryczy wynikającej z poczucia niemożności czy izolacji. Dziennik Kisielewskiego jest również demonstracją odmowy ograniczania życia do ram wyznaczanych poczuciem „powinności". Pisarz zdaje się przypominać (sobie oraz wyobrażonemu czytelnikowi), że oprócz tego, „co trzeba”, istnieje jeszcze wymiar rzeczy nieredukowalny do dnia dzisiejszego i polityki, nawet jeśli tę ostatnią rozumiemy idealistycznie jako przestrzeń walki o lepszy świat. Dla autora Rzeczy matych wymiarem tym były sztuka, przede wszystkim muzyka, oraz relacje międzyludzkie, zwłaszcza rodzinne. Swoistą pociechą, ale i źródłem poczucia siły, była także silna wiara „pomimo wszystko” w siłę słowa pisanego. Sam był mistrzem w posługiwaniu się orężem, jakim mogą być dobrze użyte: żart, złośliwość, ironia, autoironia, przekora, kpina, szyderstwo.

\section{IV}

Żart, złośliwość, ironia, autoironia, przekora, kpina, szyderstwo... Sugestywność diagnoz diarysty wynika w dużej mierze właśnie z umiejętności zręcznego posługiwania się tymi środkami i traktowania ich jako oręża w walce z oponentami. To one przede wszystkim nadają dziennikowi Kisielewskiego charakter „mówiony”, anegdotyczny i brulionowy, obnizają i „zabrudzają” jego styl („he, he"), stwarzając nieodparte wrażenie absolutnej szczerości narratora (ten przecież zamiast ważyć i cyzelować swe sądy, mówi „prosto z mostu”), zachęcającej czytelnika do wyrozumiałości tam, gdzie te sądy są pochopne czy niesprawiedliwe.

Skłonność autora Śledztwa do żartu i intelektualnej przewrotności została oczywiście wielokrotnie opisana. Niekiedy wręcz stawała się naczelną cechą jego portretów ukazujących go jako „Pierwszego Obywatela Rzeczpospolitej Rogatych Dusz” czy „Stańczyka Polski Ludowej”" ${ }^{11}$ Z lekką przesadą

11 Por. Stańczyk Polski Ludowej. Rozmowa z prof. Stanistawem Stomma [w:] J. Pruszyńska (prowadząca rozmowy), Kisiel, Warszawa 2007; M. Wiszniowska, Stańczyk Polski Ludowej. Rzecz o Stefanie Kisielewskim, Katowice-Warszawa 2004; C. Kuta, Niezależny twórca. Pod maska „btazna”, „Biuletyn IPN” 2009, nr 5-6. 
można powiedzieć, że epitety, za pomocą których próbowano uchwycić jego sylwetkę, maskę, w jakiej ukazywał się czytelnikowi, wreszcie rolę odgrywaną $\mathrm{w}$ ówczesnych warunkach były w istocie wariantami tej samej figury błazna.

W swych „rozważaniach o teologicznym dziedzictwie współczesnego myślenia”, głośnym eseju Kaptan i btazen, Leszek Kołakowski nakreślił obraz drugiego z tytułowych bohaterów jako tego:

który wprawdzie obraca się w dobrym towarzystwie, ale nie należy do niego i mówi mu impertynencje; tym, który podaje w wątpliwość wszystko to, co uchodzi za oczywiste; nie mógłby tego czynić, gdyby sam do dobrego towarzystwa nie należał (...); błazen musi być na zewnątrz dobrego towarzystwa, oglądać je z boku, aby wykryć nieoczywistość jego oczywistości i nieostateczność jego ostateczności; zarazem musi w dobrym towarzystwie się obracać, aby znać jego świętości i aby mieć okazję do mówienia mu impertynencji ${ }^{12}$.

Wyróżnikami błazna, a zarazem jego raison d'être, są więc dwuznaczny status (bycie jednocześnie na zewnątrz i wewnątrz świata, który krytykuje), a także zawarty w jego działaniu potencjał anarchizmu, niebezpieczny dla każdego systemu i dla każdej władzy.

Niebezpieczny, ale i pożyteczny, dopowiada w tym miejscu Piotr Bogalecki, zauważając na marginesie Króla Leara:

Błazen mówi tam swojemu panu straszne rzeczy - że jest „pajacem”, ma „niewiele rozumu”, że można go porównać do „zera bez cyfry”, że stał się „niczym”, podczas gdy on sam pozostaje przynajmniej błaznem, że jest zaledwie „cieniem” siebie itd. a jednak bardzo przecież porywczy Lear nie reaguje, ograniczając się do pustych gróźb. Czytając dramat Szekspira, zauważyć można znamienną prawidłowość: dopóki Lear słucha błazna, który gada i gada, dopóty zachowuje resztki rozsądku. Dyskurs chroni przed upadkiem w szaleństwo, ale $\mathrm{i}$ - jak pokazuje nam początek Leara - przed rozpadem państwa. Dyskurs ów musi być produkowany - a humaniści potrafią robić to akurat nie najgorzej. Sęk w tym, że słuchanie, o jakim mowa, jest w gruncie rzeczy puszczaniem mimo uszu - raczej słyszeniem niż słuchaniem, rozumianym w sensie przyjmowania do wiadomości. Gdyby Lear naprawdę słuchał błazna, mógłby jeszcze, choćby połowicznie, zapobiec katastrofie. Władzy nie chodzi jednak o to, aby się czegokolwiek ze słów błazna nauczyć - żąda od niego wyłącznie słów, których nieprzerwana produkcja pomaga jej zakamuflować fakt, że jest ona znacznie bardziej błazeńska niż on ${ }^{13}$.

12 L. Kołakowski, Kaptan i btazen (Rozważania o teologicznym dziedzictwie wspótczesnego myślenia) [w:] tenże, Nasza wesota apokalipsa. Wybór najważniejszych esejów, wybór, układ Z. Mentzel, Kraków 2010, s. 78.

13 P. Bogalecki, Dyletant, amator, btazen - postacie pojęciowe humanisty, „Autobiografia” 2017, nr 2 (9), s. 30-31. 
Jeśli jednak żarty błazna ratują władcę przed popadnięciem w szaleństwo, dzieje się tak dzięki temu, że ów błazen zawsze i w każdej sytuacji pozostaje w zgodzie ze swym rozumem. Warunkiem „normalności” władcy jest więc „normalność” jego błazna, i od niej, rzec można, zależą losy królestwa i jego mieszkańców. Bez tej cechy - nazwijmy ją poczuciem realizmu - błazen jest tylko zwykłym kuglarzem. Poczucie realizmu czyni z błazna melancholika, istotę zabawną i smutną jednocześnie, świadomą tragikomicznej natury świata i faktu, że profesja, jaką wykonuje, nie polega wyłącznie na odgrywaniu roli przed widzami, lecz jest w istocie sposobem życia, że maska nie jest kostiumem - raczej rekwizytem, który wyraża pewien wymiar osobowości aktora, jego charakter i wizję świata.

Czy wcielając się w błazna, Kisielewski kierował się względami taktycznymi, świadomością, że dzięki temu może powiedzieć więcej? - nie wiemy ${ }^{14}$. Jeśli nawet nie to było główną motywacją, pisarz musiał zdawać sobie sprawę z korzyści, jakie zapewnia taki gest. Niejednoznaczność intencji wpisana w żart i ironię może być skuteczną ochroną, pozwalającą ujść skutkom gniewu możnych. $\mathrm{Z}$ humorysty łatwo uczynić niepoważnego wesołka, figlarza, a nawet wariata, ale właśnie ryzyko ośmieszenia daje mu bezpieczeństwo. Czy to dzięki temu pisarz mógł cieszyć się względną swobodą? Wątpliwe przecież, by w jakimkolwiek innym kraju tej części kontynentu jawny opozycjonista chadzał regularnie na rauty $\mathrm{w}$ zachodnich ambasadach, spotykał się oficjalnie z doradcą do spraw bezpieczeństwa ówczesnego prezydenta USA, wyjeżdżał (okresowo) na Zachód, publikował w tamtejszej prasie wywiady i krytykujące system artykuły, wreszcie - roztrząsał aktualne wydarzenia ze spotykanymi przypadkowo na ulicy prominentami reżimu ${ }^{15}$. Nie należy w tym kontekście zapominać o tym, że Kisielewskiego postrzegano jako „człowieka Kościoła”, a to w niektórych sytuacjach wystarczyło, by zapewnić mu azyl. Możliwe, że był inny jeszcze powód zastanawiającej cierpliwości władz wobec swego zadeklarowanego oponenta. Kisielewski miał silną świadomość marginalizacji elit intelektualnych w społeczeństwie socjalistycznym, utraty przez nie możliwości komunikowania się z innymi warstwami społecznymi. Kwestionował zatem zasadność jednego

14 Pozytywną odpowiedź sugeruje Kamila Kamińska, por. taż, „Felieton mocno jątrzacy”, czyli cenzura wobec publicystyki Stefana Kisielewskiego (1957-1961), „Zeszyty Prasoznawcze” 2014, nr 4 (220), s. 745 . Autorka stwierdza między innymi: „Kisielewski uważał, że musi być niepoważny, ponieważ poważnego by nie dopuścili, a pozorna błazenada zapewniała mu parasol ochronny”, dodaje jednak również: „Owo błazeństwo Kisielewskiego było wymuszoną i nierzadko przykrą dla niego rolą, czuł się bowiem często nieautentyczny i nieskuteczny" (tamże; wyróżn. K.K.).

15 Względny spokój, jakim się cieszył Kisielewski, wynikał także ze stosowanej wobec niego (do czasu) przez SB strategii, mającej ograniczyć oddziaływanie jego pism przez „niezauważanie" tekstów i ich autora. Nie znaczy to, że pisarz nie bywał wielokrotnie obiektem szykan poznanie szczegółów na ten temat pozwoliło dopiero otwarcie teczek Służby Bezpieczeństwa. Por. T. Gockowski, W świetle teczek Stużby Bezpieczeństwa [w:] Stefan Kisielewski. Kisiel. 19111991, red. R. Habielski, M. Jabłonowski, Warszawa 2011; C. Kuta, dz. cyt. 
z naczelnych mitów opozycyjnych - mitu „niepokornych” będących dla reszty narodu drogowskazem moralnym, źródłem otuchy i wzorów postaw. Środowisko ludzi krytycznych wobec władzy i gotowych swój krytycyzm artykułować, jakiego obraz wyłania się z notatek dziennika, to niewielka raczej i bynajmniej nie wolna od podziałów i wewnętrznych napięć garstka odważnych. Po 1956 roku pisarze mogli się cieszyć swobodą (względną i ograniczoną co prawda, większą jednak niż w innych krajach obozu), co wynikało przede wszystkim z tego, że o izolacji elity humanistycznej wiedziała również władza. Pod tym względem sylwetka autora Sprzysiężenia może być ciekawym przyczynkiem do naszej wiedzy na temat strategii stosowanych przez reżim wobec polskich środowisk intelektualnych.

Fakt, że także w dzienniku - a więc dokumencie „sekretnym” - pisarz nie zdejmuje maski, pozwala sądzić, że bycie błaznem nie oznaczało dla niego tylko odgrywania roli. Nie jest to co prawda ten sam błazen, którego znamy z felietonów. Jego diarystyczny odpowiednik jest mniej ostentacyjny w demonstrowaniu swej inteligencji, zdolności oratorskich, retorycznych i wizjonerstwa, bardziej samokrytyczny. Mimo to nie mamy wątpliwości, że obcujemy z tą samą osobą, wyczuloną na absurdy i sprzeczności dookolnego świata, której nieobca jest wiedza o „czarności” naszej egzystencji ${ }^{16}$. Błazen z kart dziennika autora Sprzysiężenia, podobnie jak ten z felietonów, wie, że odgrywanie swej roli „tu i teraz”, w zwasalizowanym kraju o nieracjonalnym systemie polityczno-gospodarczym pełnym złych i szkodliwych absurdów (,dom wariatów”), oznacza przede wszystkim bycie tym, kto upomina się o zdrowy rozsądek ${ }^{17}$. Dzięki niemu potrafi bezbłędnie oddzielać to, co „logiczne”, „rozsądne”, „uzasadnione”, „zrozumiałe”, od tego, co „bzdurne”, „nielogiczne” i „absurdalne”, albo też - najczęściej - po prostu „głupie”. Zaś „głupie” znaczy tu przede wszystkim niewynikające z namysłu, pochopne, motywowane złą wiarą ${ }^{18}$.

16 S. Kisielewski, Pedagogika bieli [w:] tegoż, Felietony zdjęte przez cenzurę, Warszawa 1998, s. 47, cyt. za: M. Szyszka, Droga klerka. Filozofia sztuki Stefana Kisielewskiego, Kraków 2010, s. 229. O kategorii „czarności” - tamże, s. 277-234.

17 Kisiel [S. Kisielewski], Noworoczne przestania (1971) [w:] S. Kisielewski, 100 razy gtowa $w$ ściany. Felietony $z$ lat 1945-1971, Warszawa 1996, s. 255. Tomasz Sikorski w wyborze przez Kisielewskiego maski Stańczyka dopatrzył się deklaracji politycznej: „nie chodzi tylko o wypełnienie klasycznej roli Stańczyka: napominającego, podpowiadającego, uczącego i krytykującego mędrca, poruszającego się w obrębie reżimu, ale o przyjęcie metody politycznego działania, uznania geopolitycznego status quo, dbałość o zachowanie kategorii państwa, ułomnego, kalekiego, niesuwerennego w pełni, ale jednak państwa polskiego”. T. Sikorski, „Ale cóż robić, kiedy Rosje tak trudno kochać...”, dz. cyt., s. 123.

18 Marcin Król, sięgając w odniesieniu do Kisielewskiego po określenie „realista”, wyjaśniał: „(...) realistą jest ten, kto nie tylko uwzględnia możliwie wszystkie czynniki kształtujące sytuację polityczną, ale kto rozważa również, czy i jakie środki można w danej sytuacji zastosować". M. Król, Wstęp [w:] S. Kisielewski, Polityka i sztuka, Warszawa 1998, s. 7. Choć pretekstem do tego wniosku były dla autora polityczne felietony pisarza pisane tuż po wojnie, z całą pewnością można go odnieść także do dziennika. 
Zdrowy rozsądek pozwala błaznowi także zobaczyć wyraźnie paradoksalność swych działań. Czy bowiem wobec tak zdecydowanie pesymistycznej oceny możliwego rozwoju wydarzeń, ewidentnej nieracjonalności systemu jako takiego, wreszcie fasadowości jakiejkolwiek oficjalnej debaty publicznej ma sens kruszenie kopii o sprawy konkretne i wyrywkowe? Czy w tej sytuacji zasadne jest prowokowanie dyskusji, podejmowanie interwencji, wskazywanie niedostatków czy absurdów rzeczywistości? Elementarna logika każe zaprzeczyć, a to z kolei wyjaśnia w pewnym stopniu, dlaczego swój status „oficjalnego opozycjonisty” traktował pisarz ze sporą dozą „,łłazeńskiej” autoironii.

Można powiedzieć, że prezentowane przez Kisielewskiego w dzienniku poczucie realizmu jest siłą skierowaną przeciw zdrowemu rozsądkowi rozumianemu negatywnie, a więc jako - by posłużyć się słowami Antonia Gramsciego -

sposób myślenia charakterystyczny dla grup podporządkowanych, który charakteryzuje się heterogenicznością, prostotą, brakiem krytycyzmu, odwoływaniem się do bezpośredniego doświadczenia, gwałtownością, naiwnym realizmem, historycznym usytuowaniem ${ }^{19}$.

Diarysta będzie podkreślał cynizm i interesowność przedstawicieli partyjnej elity, w opisie ogółu społeczeństwa uwydatni przede wszystkim inercję i myślowy konformizm, przywiązanie do kulturowych dogmatów, brak krytycyzmu. W tym kontekście szczególnie często przywoływać będzie słowo mit, świadom jego ambiwalentnego potencjału - integrując wspólnoty, dostarczając ożywczej pociechy zgnębionym, sprzyja on zarazem ich zamykaniu się w narcystycznym samouwielbieniu, jest „wymysłem koniecznym”, szkodliwym i niezbędnym jednocześnie ${ }^{20}$. Swoje powołanie jako pisarza utożsami natomiast ze stałą gotowością do weryfikowania zbiorowych narracji i obiegowych prawd.

19 M. Wróblewski, Wierni jako zasób kontrhegemoniczny. Spór o krzyż w kontekście teorii hegemonii, „Kultura Popularna” 2014, nr 1 (39), s. 19.

20 Przywołuję tu znaną formułę Homiego Bhabhy, gdyż, jak sądzę, odpowiada ona temu, co Kisielewski określał za pomocą pojęcia „mit”. „Wymysł konieczny” definiował badacz jako opowieść, sugerującą, iż jej związek z realnością jest „zasadniczo niezapośredniczony”, i mimo że w istocie jest dokładnie odwrotnie (a być może właśnie dlatego), opowieść ta dostarcza społeczności treści o charakterze tożsamościowym i integrującym. H. Bhabha, Representation and the Colonial Text: A Critical Exploration of Some Forms of Mimeticism [w:] The Theory of Reading, red. F. Gloversmith, Brighton 1989, s. 94. O Kisielewskim jako „łowcy mitów” pisał między innymi Krzysztof Łęcki. Por. tenże, Inny zapis. „Sekretny dziennik” pisarza jako przedmiot badań socjologicznych. Na przyktadzie „Dzienników”Stefana Kisielewskiego, Katowice 2012, s. 188-193. Emilia Kledzik zasadnie mówi w tym kontekście o „wytwarzaniu tradycji”, „która jest osadzona w historycznym continuum, totalna i nieznosząca sprzeciwu. Wytycza obiektywny porządek rzeczy - tak historycznie, jak kulturowo - i w tym sensie opowiada o rzeczywistości, a nawet ją projektuje. Mówi o przeszłości i przyszłości wspólnoty, pokazuje możliwe wybory i sugeruje decyzje, grozi konsekwencjami, dokonuje apoteoz i detronizacji”. E. Kledzik, „Necessary fictions” w polskiej prozie po 1989 roku, „Porównania” 2013, nr 13, s. 130. 
Swym współczesnym oszołomionym narcystyczną martyrologią i kompensacyjnymi wmówieniami zaproponuje Kisielewski rodzaj mitologicznego ascetyzmu. Zamiast podwyższania romantycznej gorączki - mądry, choć mało efektowny „szwejkizm”:

Postawa hurrapatriotyczna, głoszona przez moczarowców, jest w istocie ideologią dostarczania Rosji mięsa armatniego. Przy pomocy Rosji możemy wprawdzie raz na zawsze zniszczyć Niemców, ale za to sami staniemy się raz na zawsze sowieccy, azjatyccy. Jeśli polskość jest czymś samoistnym i humanistycznie atrakcyjnym, powinna ona na tym „carrefourze” dziejów przybrać sobie maskę ochronną niepełnego zaangażowania - szwejkizm, pewien sceptycyzm, szerokość spojrzenia. Oczywiście, trzeba z tym ostrożnie, aby się społeczeństwo nie zdegenerowało, ale Czechom ta rzecz służyła dla ochrony swej indywidualności - może służyć i nam. Gwałtowny aktywizm ideowo-patriotyczny narodu słabego, niesamodzielnego $i$,tranzytowego" byłby rzeczą śmieszną (s. 158-159).

Takie przekonanie wyznaczy nie tylko jego własną wizję przeciwstawiania się opresji, ale i jego oceny działań innych:

A tu znów w Rosji aresztowali jakiegoś biedaka, który przesyłał na Zachód rękopisy. Zamkną go do domu wariatów, bo tam teraz taka moda. I pomyśleć, że ten niewątpliwy bohater poświęca się za nic, za fikcję, że gest jego po paru dniach zejdzie z łamów „wolnej prasy” i już nigdy na nie wróci. Okrutni są ci ludzie Zachodu, a przy tym jakże lekko- czy bez-myślni: toć jak na nich przyjdzie ta choroba, nie będą zbrojni w żadną wiedzę, w żadne doświadczenie. Życzę im wszystkiego najgorszego, no bo niby co my tu mamy do stracenia? (s. 404, wyróżn. M.K.)

Gdzie uczył się Kisielewski swego bezkompromisowego realizmu? Na przekór rodzinnej tradycji dość wcześnie utożsamił się z tą częścią tradycji polskiej myśli politycznej, którą określić można jako konserwatywną. Wśród jego fascynacji były: krakowska szkoła historyczna, Hotel Lambert, konserwatyzm w wydaniu „Buntu Młodych” i „Polityki” Jerzego Giedroycia ${ }^{21}$. Był także Roman Dmowski. W realizacji koncepcji Myśli nowoczesnego Polaka zobaczył pisarz szansę na syntezę dwu pierwiastków konstruujących polską duszę, mentalność i - ostatecznie - historię, mianowicie „temperamentu narodowego, uczuciowej i ideowej głębi, żarliwości, wysokiej temperatury duchowej natury polskiej - z racjonalizmem, dyscypliną, powściągliwością, zdolnością do narzucania sobie kompromisowej metody działania" ${ }^{22}$. Nie znaczy to jednak, że winniśmy zaliczyć Kisielewskiego do obozu zwolenników czy wyznawców

${ }^{21}$ Por. M. Szyszka, dz. cyt.

22 S. Kisielewski, O ideologię polityczna nowoczesnego Polaka (1946) [w:] tegoż, Polityka i sztuka, dz. cyt., s. 19. Charakteryzując „kisielizm”, Wojciech Karpiński podkreśli związek 
endecji. Postać i jej poglądy - z jednej, a polityczne skutki tych poglądów z drugiej strony - to dla niego dwie odrębne kwestie i bodaj w przypadku twórcy Narodowej Demokracji różnica ta widoczna jest najbardziej. Uznając znaczenie myśli Dmowskiego jako części polskiej tradycji politycznej, pisarz upomina się o wznowienia jego pism, w dzienniku niejednokrotnie powoła się na jego autorytet, zarazem jednak zdobędzie się na surową ocenę: „Dziwny zresztą działacz i mąż stanu, rzeczy arcymądre sąsiadują w nim z arcynonsensami” (s. 685) ${ }^{23}$.

Estymę, z jaką traktował Kisielewski Dmowskiego, można by uznać za nieszkodliwy ekscentryzm intelektualisty. Jednak choć - jak zauważyliśmy - nie oznaczała ona braku krytycyzmu i nie wykluczała polemik, mimowolnie nasuwa myśl o ryzyku, z jakim wiąże się posunięty do skrajności pragmatyzm. Wydaje się, że to właśnie pragmatyzm i swoiście rozumiana zasada Realpolitik kazały mu częstokroć nie liczyć się z aspektami prawnymi, społecznymi czy wręcz etycznymi zjawisk i oceniać je zimnym okiem stratega. W takiej optyce nadrzędną kwestią jest walka z komunizmem, przyjaciółmi zaś wszyscy, których działania sprzyjają jego pokonaniu. Konsekwencja w przyjmowaniu takiej postawy sprawiła, że niektóre wybory pisarza mogą dziś budzić zdziwienie choćby podziw, jaki żywił dla Francisca Franco oraz Richarda Nixona, którego bronił nawet po ujawnieniu skandalu podsłuchowego, pokazując swe niezrozumienie znaczenia, jakie dla funkcjonowania demokracji ma wolna prasa.

Na szczęście Kisielewski świadom był również ograniczeń realizmu utożsamianego z przekonaniem, że „wszystko jest do ogarnięcia”. W tym kontekście "głupota” okazuje się nie tyle brakiem rozumu, ile raczej skutkiem nieliczenia się z tym, czego ten nie jest w stanie objąć, a także pominięciem faktu, że posunięty do skrajności rewizjonizm tworzy świat „pusty i nudny”24. Traktowany krytycznie realizm jest pociskiem wystrzelonym w racjonalizm dogmatyczny i ograniczony, w racjonalizm, który stworzył „wiek światła”, ale i obozy koncentracyjne, ponieważ w swoich rachunkach zapomniał o tym, co w człowieku nie poddaje się całościowemu opisowi. Błąd dogmatyzmu zarzucał pisarz między innymi Antoniemu Słonimskiemu, jednemu z głównych czarnych

umysłowości Kisielewskiego z neopozytywizmem. Por. W. Karpiński, Kisielizm jako duchowa forma życia [w:] tegoż, Prywatna historia wolności, Warszawa 1997.

23 Podsumowując obecność Dmowskiego w dzienniku pisarza, Krzysztof Łęcki pisał zasadnie: „Tradycja i współczesność endecka mają dla Kisiela kilka wymiarów, które różnie ocenia. Jeden dotyczy przedwojennej endecji (konkretnie: ideologii, ponieważ na temat praktyki Ruchu Narodowo-Demokratycznego Kisiel w Dziennikach zasadniczo się nie wypowiada). Określić go można jako warunkowo pozytywny - to, co Kisiel akceptuje, to jego antykomunizm (...). Natomiast ocena powojennych dziejów bądź przetrwalnikowych form instytucjonalnych endecji (grupa Bolesława Piaseckiego), czy też - tym bardziej - wizji świata i propagandy, odwołujących się do »endeckich sentymentów“, wypadają już zdecydowanie negatywnie”. K. Łęcki, dz. cyt., s. 332.

24 S. Kisielewski, „Mitologia” zwycięża! [w:] tegoż, Polityka i sztuka, dz. cyt., s. 151. 
charakterów dziennika ${ }^{25}$. Dla niego samego tymczasem owym obszarem, który nie podlega rozumowi, będzie przede wszystkim religia - jedyna mitologia, którą zdolny był zaakceptować, tworząca w jego umyśle przeciwwagę dla świata bezkompromisowej kalkulacji.

Potencjał swego realizmu wykorzystał Kisielewski w krytyce rzeczywistości zdominowanej przez przerośniętą ponad miarę sferę zbiorowych symboli i mitów. Tę rzeczywistość starał się opisywać ze stanowiska możliwie najbardziej wolnego od myślowych przed-sądów, skażenia ideologiami czy innymi prawdami nie dość osadzonymi w empirii. Pomogła mu w tym maska błazna, stwarzająca perspektywę, z której widać równie dobrze ideowych rywali, jak i sojuszników. Ironia, autoironia i wynikający z humoru dystans do świata i ludzi nie tylko zapewniają błaznowi bezpieczny azyl, chroniąc go przed zemstą „,sług systemu”, lecz i pozwalają uniknąć większości zagrożeń, jakie niesie z sobą zaufanie w rozum. Maska błazna chroni przed dogmatyzmem, nie pozwala na podporządkowanie się bez reszty pragmatyce walki z wrogiem, na zawężenie życia do pola bitwy. Ważniejsze bowiem niż pokonanie wroga jest zachowanie jednostkowej autonomii w sytuacji, gdy świat zainteresowany jest odebraniem nam jej za wszelką cenę.

Bycie „mądrym błaznem” było dla Stefana Kisielewskiego sposobem na uchylenie się od kondycji ofiary.

\section{Bibliografia}

Bhabha H., Miejsca kultury, tłum. T. Dobrogoszcz, Kraków 2010.

Bhabha H., Representation and the Colonial Text: A Critical Exploration of Some

Forms of Mimeticism [w:] The Theory of Reading, red. F. Gloversmith, Brighton 1989.

25 Na stosunek Kisielewskiego do skamandryty rzuca światło przedwojenny artykuł Terroryzm ideowy, w którym przyszły autor Sprzysiężenia przedstawił trzy - w jego opinii - najbardziej wówczas wpływowe, a zarazem szkodliwe, ideologie: komunizm, ONR-yzm oraz „neohumanitaryzm” reprezentowany przez środowisko „Wiadomości Literackich”. Zwolennikom ostatniej opcji zarzucał, że „występując przeciw dogmatycznym, kluczowym systemom nie potrafili im przeciwstawić nic pozytywnego. Zatrzymali się na postawie negatywnej, a tworząc cały system swej negatywnej dogmatyki, stworzyli najszkodliwszy ośrodek terroru: terror bezideowości”. S. Kisielewski, Terroryzm ideowy, „Bunt Młodych” 1936, nr 3 (94), cyt. za: http://retropress.pl/bunt-mlodych/ terroryzm-ideowy/, dostęp: 5.06.2019. Wydaje się, że bezpośrednia konfrontacja z komunizmem po wojnie wyostrzyła jeszcze stanowisko pisarza w tym względzie. 
Bogalecki P., Dyletant, amator, btazen - postacie pojeciowe humanisty, „Autobiografia” 2017, nr 2 (9).

Gockowski T., W świetle teczek Stużby Bezpieczeństwa [w:] Stefan Kisielewski. Kisiel. 1911-1991, red. R. Habielski, M. Jabłonowski, Warszawa 2011.

Kamińska K., „Felieton mocno jątrzacy”, czyli cenzura wobec publicystyki Stefana Kisielewskiego (1957-1961), „Zeszyty Prasoznawcze” 2014, nr 4 (220).

Karpiński W., Kisielizm jako duchowa forma życia [w:] tegoż, Prywatna historia wolności, Warszawa 1997.

Kisielewski S., 100 razy gtowa w ściany. Felietony z lat 1945-1971, Warszawa 1996.

Kisielewski S., Dzienniki, wprowadzenie L.B. Grzeniewski, Warszawa 1996.

Kisielewski S., Pedagogika bieli [w:] tegoż, Felietony zdjęte przez cenzurę, Warszawa 1998.

Kisielewski S., Polityka i sztuka, Warszawa 1998.

Kisielewski S., Terroryzm ideowy, „Bunt Młodych” 1936, nr 3 (94).

Kledzik E., „Necessary fictions” w polskiej prozie po 1989 roku, „Porównania” 2013, nr 13.

Kołakowski L., Kaptan i btazen (Rozważania o teologicznym dziedzictwie wspótczesnego myślenia) [w:] tenże, Nasza wesota apokalipsa. Wybór najważniejszych esejów, wybór, układ Z. Mentzel, Kraków 2010.

Król M., Wstęp [w:] S. Kisielewski, Polityka i sztuka, Warszawa 1998.

Kuta C., Niezależny twórca. Pod maskq „btazna”, „Biuletyn IPN” 2009, nr 5-6. Lejeune Ph., „Drogi zeszycie...”, ,drogi ekranie...". O dziennikach osobistych, thum. A. Karpowicz, M., P. Rodakowie, wybór, wstęp P. Rodak, Warszawa 2010. Łęcki K., Inny zapis. "Sekretny dziennik” pisarza jako przedmiot badań socjologicznych. Na przyktadzie „Dzienników” Stefana Kisielewskiego, Katowice 2012.

Nowak A., Powrót do Polski. Szkice o patriotyzmie po „końcu historii”, Kraków 2005.

Rodak P., Prawda w dzienniku osobistym, „Teksty Drugie” 2009, nr 4.

Sikorski T., „Ale cóż robić, kiedy Rosję tak trudno kochać... "Refleksje nad realizmem politycznym Stefana Kisielewskiego [w:] Rosja w polskiej myśli politycznej XXXXI wieku, red. A. Lewandowski, W. Wojdyło, G. Radomski, Toruń 2013.

Stańczyk Polski Ludowej. Rozmowa z prof. Stanistawem Stomma [w:] J. Pruszyńska (prowadząca rozmowy), Kisiel, Warszawa 2007.

Stasiński P., Poetyka i pragmatyka felietonu, Wrocław 1982.

Szyszka M., Droga klerka. Filozofia sztuki Stefana Kisielewskiego, Kraków 2010.

Wiszniowska M., Stańczyk Polski Ludowej. Rzecz o Stefanie Kisielewskim, KatowiceWarszawa 2004.

Wiszniowska M., Sztuka felietonu Stefana Kisielewskiego, Katowice 2013.

Wróblewski M., Wierni jako zasób kontrhegemoniczny. Spór o krzyż w kontekście teorii hegemonii, „Kultura Popularna” 2014, nr 1 (39). 